\title{
Towards a Gramscian food regime analysis of India's agrarian crisis: counter-movements, petrofarming and Cheap Nature
}

This article develops an initial framework for a Gramscian and political ecological food regime analysis of India's ongoing agrarian crisis. Criticizing readings of Polanyi in food regime analysis in light of Gramscian perspectives, I seek to contest food regime analysis's approach to counter-movements. I suggest, further, that close attention to the Indian case of 'actually existing crises' helps us avoid some of the capital-centric limitations in food regime literature. Working towards an incipient understanding of the absence of a sustained smallholder counter-movement at the current conjuncture in India, I argue for locating our investigation at the intersection of crises of accumulation and of legitimation. I analyze India's decentralized form of petrofarming as a socioecological cycle of accumulation that is presently facing a condition of exhaustion of Cheap Nature. Drawing on Gramscian perespectives, I argue that an analytics that foregrounds the dynamics of class forces in the integral state can help us rethinking the possibilities for resistance to the contemporary food regime more broadly.

Keywords: food regime analysis, Gramsci, political ecology, agrarian crisis, India

\section{INTRODUCTION}

Crisis seems to be everywhere. 'Crisis', writes Janet Roitman, 'is an omnipresent sign in almost all forms of narrative today' (Roitman 2014, 3). Such is the case also for one of the most influential approaches to the spatiotemporal study of food and agriculture in global capitalism, namely food regime analysis. Here, historically emergent international food regimes are perceived to evolve around periods of stability and periods of crisis centered on cycles of capital accumulation in combination with the formation and crumbling of legitimizing rules and relationships (e.g. Friedmann 2005, Friedmann and McMichael 1989, Magnan 2012, McMichael 2013). In an organicist metaphor, it is through crises that food regimes die while giving birth to new regimes. Particular emphasis is placed on the role of social movements in triggering and resolving crises. In Philip McMichael's prominent writings, a global peasant counter-movement uniting for food sovereignty is seen as the response to the contemporary, third 'corporate food regime' that brings rising dispossession, disturbance and destruction for smallholders and environments worldwide (e.g. McMichael 2009b, 2013). These deleterious sides of the contemporary food regime are perceived as 
Jostein Jakobsen, accepted version, Geoforum

amounting to a global agrarian crisis: 'capital's food regime has generalized an agrarian crisis of massive proportions, registered now in a growing movement to stabilize the countryside, protect the planet, and advance food sovereignty' (McMichael 2013, 19). The Polanyian counter-movement, in McMichael's rendering, is showing the way forward - even beyond the contemporary food regime - to a more just future.

Following such a view of food regime dynamics, we should expect sizeable countermovements, rallying for their right to smallholding farming, gathering forces in places where agrarian crisis takes its toll. India is one such place. In fact it is a striking one. Since the early 1990s the country has registered a situation of deteriorating livelihoods for smallholders epitomized in the globally prominent spates of farmers' suicides often described as 'epidemic' - which presently routinely is seen as an agrarian crisis. Yet in India countermovements are equally striking in their absence. No major farmers' movements are presently shaking the earth with their cries for justice. For example, a recent review of countermovements in the country shows that, although neoliberal capitalist restructuring has brought increasing social dislocations causing the mushrooming of new, often dispersed countermovements, these have not been of and for smallholder farmers in anything akin to McMichael's peasant resurgence (Sahoo 2017). The counter-movements that India does house in the neoliberal period are mostly urban middle-class based forms of 'law-struggles' (Harriss 2011, Sundar 2011). Why is it so? And how can we make sense of this in a food regime perspective?

This article aims to provide the groundwork for a distinct food regime analysis of India's agrarian crisis. Central here is an effort at incorporating the role of social movements in the agrarian crisis and its effects. I do so by developing a framework for a food regime analysis that is Gramscian (1971) and political ecological (Castellanos-Navarrete and Jansen 2017, Loftus 2013, Mann 2009). Such conceptualization is not altogether novel, as its traces are 
Jostein Jakobsen, accepted version, Geoforum

found latent in food regime literature. Elaborating such a framework provides us, I suggest, with useful tools for studying food regime crises and counter-movements elsewhere.

Although the reinterpretation and synthesizing of existing empirical material comprises an important and necessary first step, the present contribution is not merely an exercise of 'old wine in new bottles'. A Gramscian food regime analysis - taken as an 'analytical device' (McMichael 2009b, 148) - of the agrarian crisis enables an understanding of what, following Marx, we can call the 'rich totality of many determinations and relations' (Marx 1973, 41). ${ }^{1}$ At the core of what makes a food regime work are relations between capital and labor as mediated by states in the world-system but, importantly, also 'the distillation of political struggles among contending social groups' (McMichael 2013, 11). Capital, labor, states, class struggle: all converge - tension-fraught and contradictory - in the food regime. Moreover, as Jason Moore forcefully contends, all of these relations are socioecological - bundled in and through the web of life - necessitating that we 'focus our attention on the concrete dialectics of the messily bundled, interpenetrating, and interdependent relations of human and extrahuman natures' (Moore 2015, 35). At the core of what makes a food regime stop working the formation of crisis - we thus likewise find bundles of socioecological relations. These comprise two mutually constitutive tendencies: accumulation crisis and legitimation crisis.

I argue that the close study of agrarian crisis in India opens for questioning some of the fundamental theoretical tenets and assumptions in food regime analysis. As I will proceed to elaborate, recent criticism of food regime analysis has questioned the role ascribed by McMichael to the global food sovereignty counter-movement. Whereas Henry Bernstein's (2016) penetrating reading criticizes McMichael's reliance on Chayanovian organicist understandings of the 'peasantry', I seek to take the discussion in another direction by

\footnotetext{
${ }^{1}$ Food regime analysis, as McMichael recapitulates it, was and remains founded on the study of 'the multiple determinations in the food commodity' (McMichael 2016, 655).
} 
Jostein Jakobsen, accepted version, Geoforum

focusing on the role readings of Polanyi have in food regime theory. The empirical case of India's agrarian crisis helps us see some limitations to the prevailing Polanyi-derived focus on relations between the market and society - smallholders, in this case - as a counterhegemonic force. While eminently fruitful in many contexts, this analytic disregards Gramsci's complementary focus on relations between the state and society, taking the latter to be intrinsic to the formation of capitalist hegemony in an expanded notion of the state (Burawoy 2003). Drawing on Gramsci, I thus argue that India's agrarian crisis constitutes a conjuncture where both accumulation crisis and legitimation crisis are present but where their co-presence does not, in fact, lead to counter-movements as in McMichael's scheme; this is exactly because of how class forces in society have been instrumental in consolidating capitalist hegemony in India's integral state. The agribusiness versus smallholder binary (Bernstein 2016) that is embedded in McMichael's scheme should therefore be treated with caution. Whereas food regime analysis tends to attend to processes of accumulation 'from above', the case of India's actually existing crisis thus shows the need to attend also to class specific processes of accumulation 'from below'. Put differently, we need to take heed of the co-production of accumulation cycles and class dynamics.

In light of this, I seek to problematize the theory of resistance embedded in food regime analysis. If we take the agrarian crisis to constitute an 'organic crisis' in Gramsci's (1971) sense, I propose caution in taking on board the food regime approach's Polanyian idea of a necessary double movement (Polanyi 2001 [1944]). Organic crisis, in Gramsci, entails that 'the structures and practices that constitute and reproduce a hegemonic order fall into chronic and visible disrepair, creating a new terrain of political and cultural contention, and the possibility (but only the possibility) of social transformation' (Carroll 2010, 170-171). A Gramscian food regime analysis that takes heed of constellations and trajectories of class forces and state-society relations reveals the fragility of such possibility. Likewise, a 
Jostein Jakobsen, accepted version, Geoforum

Gramscian analysis of the consolidation of hegemonic projects needs to emphasize their fragile and contested nature. While I focus on the politics of consent, Gramscian analytics necessarily incorporate its articulation with coercion. It is clear that the Indian state is capable of heavy coercion unleashed upon movements perceived by the state as threatening, such as in the case of the Maoists in parts of India (see e.g. Das 2017, Sundar 2016) - or, under Narendra Modi recently, parts of civil society (Sinha 2017). The near absence of coercive methods in the case of smallholders can thus be seen as a sign, precisely, of the near absence as well of sustained counter-movements.

In developing this framework I seek to address another shortcoming in food regime analysis: Despite the crucial theoretical importance ascribed to crisis, the literature has largely refrained from taking head-on 'actually existing crises'. To the extent that actually existing crises have been invoked, it has primarily been in the context of the 'world food crises' of 1972-3 (Friedmann 1993) and 2007-8 (Holt Giménez and Shattuck 2011, McMichael 2009a, c). Agrarian crisis, which figures centrally in McMichael's most recent formulations of the 'fundamental contradiction' of the corporate food regime (McMichael 2013, 60), has been largely left empirically undescribed. India’s ongoing agrarian crisis - of world-historical proportions - is an appropriate place to go for downscaling food regime analysis to the level of actually existing crises. This also enables us to surpass some of the limitations found in the literature's tendency to operate with highly abstract schemes of phases and dynamics that border on the generic (cf. Bernstein 2016). Grounding food regime analysis in particular spatiotemporal settings 'demands a detailed mapping of specific powers and structures', as William Roseberry $(2002,77)$ puts it. This can serve as an entry to contributing to the ongoing work of downscaling food regime analysis more broadly, aiming for

a food regime analysis with suitable theoretical mediations about class structures and states; methodological sophistication with units of analysis below the world-system, including world 
Jostein Jakobsen, accepted version, Geoforum

regions and nation states; and political sensitivity toward the subordinate classes as a whole, not merely the peasantry' (Otero 2016,303).

This is an important task in a context where food regime analysis so far has operated at the level of the world economy with a 'broad brush' (Otero 2012, 283), inviting historicalgeographical elaboration through detailed case studies (McMichael 2013, 96, Otero 2012, Otero, Pechlaner, and Gürcan 2013). The case of India has hardly figured in such an analytical project. And the few existing studies do not go very far in systematically 'bridging the gap' between India and food regime analysis. ${ }^{2}$

The article is structured as follows. The first section revisits the interrelations between food regimes, crisis and social movements, elaborating my take on a Gramscian and political ecological food regime framework. The next section proceeds to drive home the proposition that India's agrarian crisis indeed is a food regime crisis. It does so by tracing the trajectory of the agrarian crisis 'as a process and relation' (Araghi 2009, 142) through the 'long' Green Revolution (Patel 2013) - arising at the height of the second food regime - as a cycle of accumulation that has now reached its socio-ecological limit in the context of neoliberal capitalist restructuring of the state's relationship to agriculture, despite attempted 'fixes'. This is to say that I analyze the agrarian crisis as a crisis of India's particular, decentralized form of agrarian capitalism - what we can call 'petrofarming' (Walker 2004). In this perspective, it appears that the ongoing crisis sees a model of agriculture shaped in the second food regime, while now 'carried over' (Pritchard 2009) to encountering elements of an emergent neoliberal third regime, undergoing an exhaustion of Cheap Nature (Moore 2015). It thus follows that the absence of sustained counter-movements likewise needs to be understood in the context

\footnotetext{
${ }^{2}$ Existing studies that engage food regime analysis with reference to India are limited to India being used as an example in broader analyses (Patel 2013, Pritchard et al. 2016), as passing reference (Lerche 2013), as background/context (Gupta 1998) or by 'throwing the baby out with the bathwater' in dismissing food regime analysis (Frödin 2013).
} 
Jostein Jakobsen, accepted version, Geoforum

of the trajectory of class forces in the countryside through the long Green Revolution. We find that this longer view captures processes whereby agrarian capitalists have attempted to mobilize for their class interests, for then gradually to diversify out of agriculture. In the contemporary neoliberal period few class forces are around to take upon themselves the task of progressive mobilization for the cause of smallholders. Resistance to the crisis thus appears inextricably entangled with the specific form of the dominant class forces in the integral state.

\section{FOOD REGIMES, CRISIS AND SOCIAL MOVEMENTS}

Central to the idea of a food regime is the 'subjection of international circuits of foodstuffs to a governing market price'(McMichael 2013, 24). While the idea of a contemporary, third food regime - emergent from the 1980s onwards - is contested, scholars by and far agree about the classification of the prior regimes. The most common periodization sees a first food regime, centered on the British Empire and the flow of agricultural commodities from peripheries to the core, existing between 1870 and 1914; then leading to a transition period and the emergence of a post WWII second regime, centered now on US dominance in the era of developmentalism, which subsequently fell apart in the midst of the early 1970s global food crisis (Friedmann and McMichael 1989, Friedmann 1993). Even though these two first regimes were explicitly related to transformations in capitalism, they also appear relatively stable. The very stability of their functioning and composition even form part of their definition, in some instances, such as in Friedmann's early definition of the food regime as 'the rule-governed structure of production and consumption on a world scale' (Friedmann 1993, 30-31); or, in a more recent formulation by McMichael: 'food regime analysis brings a structured perspective to the understanding of agriculture and food's role in capital accumulation across time and space' (McMichael 2009b, 140). Stability and crisis comprises 
Jostein Jakobsen, accepted version, Geoforum

part of any regime's inherent spatiotemporal contradictions (McMichael 2013). Whereas transformation, transition and crisis must thus be seen as inherent to the analytical framework, these appear more pressing and controversial in the contemporary third regime.

Bernstein's (2016) recent critique notes that despite the important role ascribed to social movements in food regime analysis, it is first with the third food regime that social movements really have become prominent, particularly so in McMichael's focus on the global peasant counter-movement La Via Campesina. McMichael's notion of the corporate food regime and its current crisis rests on a ‘fundamental contradiction' (McMichael 2013, 60) between global agribusiness and financialization of agriculture in the neoliberal period and its global consequence, namely the escalating dispossession of smallholders and deterioration of environments. Much of Bernstein's criticism focuses on how McMichael's conception of 'the peasantry' rests on problematic organicist notions of peasant unity in the tradition of Chayanov, thus sidestepping questions of class dynamics and differentiation. ${ }^{3}$ Bernstein charges McMichael for introducing a 'binary' conceptualization of the contemporary food regime and its crisis, that is, the 'binary between global agribusiness capital [...] and small farmers' (Bernstein 2016, 639). To a large extent, then, the debate that is currently raging in food regime literature revolves around the meaning of 'agrarian capitalism':

In general terms one view is of an agrarian capitalism, in the form of a global food regime, which is homogenous, top-down, systemic, corporate, external and without subjects; the other is a view of agrarian capitalism that recognizes multiple forms, is internal and is shaped by class differentiation, complex alliances and contradictions (Jansen 2015, 218).

\footnotetext{
${ }^{3}$ Closely related are wider debates around the issue of agrarian 'populism' (see e.g. Brass 2015).
} 
Jostein Jakobsen, accepted version, Geoforum

Exploring the role of capitalist farmers in the agrarian crisis, I seek to pry open the effects of their 'relentless micro-capitalism' (Davis 2006, 181) rather than that of an exogenous 'macrocapitalism' (Bernstein 2014, 1044). Yet I do so with the intention to contribute, in line with Otero's mentioned call, to the downscaling and historical-geographical elaboration of food regime analysis.

\subsection{Accumulation crisis}

Food regime analysis is based in an interest in exploring the spatiotemporal dynamics of how, to paraphrase Marx $(1976,895)$, the world's soil has been incorporated into capital. Food regime crises are seen as constituted through capital - that is, in the ebb of waves or cycles of accumulation. In his recent discussion of crisis formation, McMichael perceives the global food crisis as involving a 'layering of spatio-temporal relations' (McMichael 2013, 110) in the contemporary food regime: 'The current crisis of accumulation combines a long-term structural feature of capitalism (under-reproduction) with a conjunctural form (financialization)' (McMichael 2013, 114). McMichael perceives the current deterioration of environments and livelihoods across the rural world to be signaling a possible crisis of exhaustion in the contemporary regime. In consonance with his Polanyian double movement analytics, he points out 'the food sovereignty movement is the most direct symptom of this socio-ecological crisis' (McMichael 2005, 298). Here, McMichael aligns his perspective closely with Jason Moore's work on the ‘capitalist world-ecology’ (McMichael 2013, 113 117).

Moore sees historical capitalism as revolving around the 'rise of Cheap Nature' (Moore 2016). This needs careful unpacking. Capitalism, in Moore's view, is an ecological regime itself (Moore 2011); a way of organizing humanity-in-nature/nature-in-humanity (Moore 2015, 49). The world-ecological approach to accumulation borrows from Arrighi (2010) in 
Jostein Jakobsen, accepted version, Geoforum

seeing cycles of accumulation as going through systemic sequences of boom and bust. Moore frames this through a reconceptualization of Marx's general law of underproduction as involving the dialectics of 'accumulation by capitalization' and 'accumulation by appropriation'. Appropriation are those processes 'through which capital gains access to minimally or non-commodified natures for free, or as close to free as it can get' (Moore 2015, 95). Cheap Nature, here, is the 'work/energy' of both human and extra-human natures. Through appropriation of Cheap Nature in 'an endless frontier process' (Moore 2015, 107), capital seeks to expand its accumulation while minimizing the rising costs of production and overproduction. 'Capitalism thrives', Moore writes, 'when islands of commodity production and exchange can appropriate oceans of potentially Cheap Natures - outside the circuit of capital but essential to its operation' (Moore 2017, 6). As accumulation cycles proceed, the ways of organizing human and extra-human nature that once brought windfalls of surplus value tend to 'progressively exhaust the relations of reproduction' (Moore 2017, 10). Such exhaustion of Cheap Nature - relative or possibly, at the current world-historical moment, absolute (Moore 2011) - are at the heart of accumulation crisis.

Both in Moore's and McMichael's schemes, historical capitalism handles accumulation crisis through reshuffling the crisis tendencies spatiotemporally; in other words, in accordance with Harvey's notion of the 'spatial fix', referring to 'capitalism's insatiable drive to resolve its inner crisis tendencies by geographical expansion and geographical restructuring' (Harvey 2001, 25). Referring primarily to the built environment, Harvey's concept can be made more germane to agrarian contexts as a 'socioecological fix' (Ekers and Prudham 2015, 2017a, b). What sets Moore's approach particularly apart from Harvey's is his focus on accumulation by appropriation and the underproduction side of the dialectic. I take this to be a fruitful analytical intervention in regard to food regime analysis. 
Jostein Jakobsen, accepted version, Geoforum

The question of whether the current conjuncture marks the end of capital's ability to displace crisis tendencies through fixes is highly controversial. There is an obvious risk of capital determinism. Moreover, as Ekers and Prudham argue, socioecological fixes are also sociopolitical processes responding to struggles over legitimacy. Bringing in Gramsci, they argue, 'pushes us to consider how a socioecological fix doubles as a hegemonic project' (Ekers and Prudham 2017b, 11). Similarly, James O'Connor long ago argued that deterioration in the 'conditions of production' (including land and labor) can bring about legitimation crises for the state (O'Connor 1998, 150). It is thus evident that we need to think of accumulation and legitimation as co-produced, mutually constitutive to food regime crises.

\subsection{Legitimation crisis}

Food regime analysis further sees crisis as revolving around the normative, legitimizing function of regimes as upholding the underpinning relatively stable relationships and rules. These relationships and rules, in Harriett Friedmann's view, tend to be implicit in times of relative stability and made explicit in crisis:

even at their most stable, food regimes unfold through internal tensions that eventually lead to crisis, that is, to an inability of the key relationships and practices to continue to function as before. At this point, many of the rules which had been implicit become named and contested. This is what crisis looks like (Friedmann 2005, 229).

As an example of how 'naming' catches on, Friedmann uses the example of how international transfers of agro-commodities went from being called 'aid' to 'dumping' (Friedmann 2005, 232-233). In such moments of legitimation crises, social movements are among the main actors shaping the trajectory of food regime transitions in naming and contesting the crisis itself (Magnan 2012). This is where food regime analysis comes closest 
Jostein Jakobsen, accepted version, Geoforum

to a Gramscian perspective, although invocations of Gramsci, hegemony and legitimation pop up sporadically in the literature. For example, Raj Patel's mention of food regime analysis 'understood in a Gramscian light' focusing on 'structures of legitimation' (Patel $2013,51)$ is highly suggestive but only takes us so far. McMichael's corporate food regime, moreover, is based on an underspecified - or inflated - concept of hegemony. In his take, it appears that hegemony equals 'rule' as 'corporate hegemony insofar as neoliberal doctrine, in elevating "markets" over "states", transforms the latter into explicit servants of the former' (McMichael 2013, 45). It is my claim that a cautious usage of such terms, coupled with a developed Gramscian approach, can help us take food regime analysis further.

This is important in regard to social movements. McMichael's reading of Polanyi and the notion of 'double movements' underpinning the alleged global reactions to the corporate food regime rests, I suggest, on a problematic organicist notion of 'society'. While Polanyi's analysis of state-society relations arguably is more nuanced than what comes across from McMichael's reading - and it is the food regime analysis variety of a Polanyian perspective I am focusing on in this paper-it is clear that Polanyi differs from Gramsci on this account (Burawoy 2003). ${ }^{4}$ Where Polanyi talks about society having a certain 'autonomy of its own' (Burawoy 2003, 206), Gramsci takes the 'integral state' to include civil society (Gramsci 1971, 263). It is through the integral state that ideas and practices of dominant social classes are spread more widely and assume legitimacy, taking on the guise of representing society as a whole - in other words, the Gramscian concept of hegemony. As Burawoy points out, the Polanyian perspective foregrounds relations between markets and society, emphasizing the latter's potential as a counter-hegemonic force. Here, Polanyi's notion of society arguably fails to understand class domination: 'For Polanyi, any class can represent its interests as the

\footnotetext{
${ }^{4}$ For other readings of Polanyi's double movement analytics which arguably are more attentive to nuance, see for example Block (2008) and Dale (2012).
} 
Jostein Jakobsen, accepted version, Geoforum

general or societal interest within capitalism' (Burawoy 2003, 229 emphasis in original). The Gramscian perspective differs in focusing instead on state-society relations and the ways by which society enfolds in the state to bring about capitalist hegemony: 'For Polanyi, society counters the market, while for Gramsci, it is an extension of the state' (Burawoy 2003, 214). Where Polanyi's notion of society is one of commonality of interests, Gramsci's is one of 'antagonistic class interests' (Burawoy 2003, 229). It thus follows that whereas the Polanyian perspective allows for defining as counter-hegemonic movements housing anything from fascism to socialism, the Gramscian perspective would not allow as a counter-hegemonic anything that is less than politically progressive (cf. Carroll 2010). Put differently, the Polanyian perspective is seemingly unfit for differentiating between 'movements from below' and 'movements from above', where the latter are fronted by dominant groups and 'aims at the maintenance or modification of a dominant structure of entrenched needs and capacities in ways that reproduce and/or extend the power of those groups and its hegemonic position within a given social formation' (Nilsen 2009, 115).

In food regime analysis, Polanyi is often an implicit - yet ever-present (sometimes explicit, see e.g. McMichael 2006) - reference point and his lasting influence on conceptualizing 'society' is not, to my knowledge, discussed at length. Gramsci, as we have seen, pops up now and then in food regime literature, but hardly in order to discuss state-society relations. It is not coincidental, then, that McMichael views food regimes as 'constituted through state/market relations' (McMichael 2013,7) and leaves it at that. Further elaborations of class struggle are largely lacking, despite focus on the global peasant counter-movement. In some degree, this is a consequence of the capital-centrism embedded in food regime analysis (McMichael 2013, 131), a limitation also found in Moore's approach insofar as it 'brackets the necessary questions of class struggles and social movements' (Moore 2011, 16). 
Jostein Jakobsen, accepted version, Geoforum

It is my contention that involving the Gramscian state-society perspective in the conversation can help us in addressing these limitations. Moreover, Gramscian approaches to the study of power and resistance in India have a strong tradition. Without going into these pedigrees at any length, it is worth pointing out that the conceptualization of state-society relations has recently been subject of critical overhaul. Drawing on stormy debates, first over Subaltern Studies and its distinctions between 'subalterns' and 'elites', and second over Partha Chatterjee's (2004) highly influential reconceptualization in terms of 'political society' and 'civil society', Gramscian scholars have come to criticize both for their binary divisions. Understanding hegemonic processes should arguably rather be seen as involving the dialectical interweaving of the 'knots of tangled power relations' (Whitehead 2015, 671) of subaltern and dominant groups through the integral state (Nielsen and Nilsen 2015). The main point for our purposes is that the idea of counter-movements in a distinct realm of society makes for a limited theory, not only of reactions to crisis and restructuring but of resistance to the contemporary food regime.

\section{INDIA'S AGRARIAN CRISIS AS A FOOD REGIME CRISIS}

Gramsci warned against thinking of crisis as linear, with a single origin: 'We are dealing with a process that shows itself in many ways, and in which causes and effects become intertwined and mutually entangled' (Gramsci 1995, 219, quoted in Ekers and Prudham 2017b, 10-11). But we always need to start somewhere.

\subsection{The petrofarming accumulation cycle}

What is a better place of departure than in the aftermath of precisely a food regime socioecological fix, emanating from the confluence of overproduction of capital and falling rates of profit in US agriculture with Cold War geopolitics? In this section I trace India's agrarian crisis as partaking in a cycle of accumulation in the web of life starting with the 
Jostein Jakobsen, accepted version, Geoforum

Green Revolution during the second food regime. My analysis thus differs from what is prevalent in the scholarship of India's agrarian crisis, which tends to foreground neoliberal economic reforms since 1991 (e.g. Narasimha Reddy and Mishra 2009a). Raj Patel (2013) has sown the seeds of such an analytics in his ambitious study of the 'long' Green Revolution moving from the early state-directed stage of the 1960s and 1970s to presently being incorporated in globalized financialization. Instead of departing from India for the latter part of the 'global' trajectory, as Patel does, we will remain rooted in Indian soil. What we discover is that, consonant with Moore's view of socioecological accumulation cycles, the early stage of the long revolution gives way, first to a gradual declining rate of profit in capitalist agriculture, second to socioecological exhaustion in the contempoary neoliberal conjuncture.

A basic caveat is necessary. Agriculture in India is highly diverse, housing a mosaic of patterns of agrarian capitalism (Lerche 2014). Generalized assessments are therefore not unproblematic. In a recent overview, Jens Lerche cautions against the 'doomsday scenario' found in McMichael's notion of the corporate food regime, saying that a 'general pauperization of all agrarian classes has not taken place' (Lerche 2013, 400). Rather, in the midst of agricultural decline there are still accumulating classes. These might even find opportunities in crisis to accumulate through speculative forms of agriculture, as Daniel Münster's (2015) ethnographic work from Kerala shows. Nevertheless, Lerche concedes that 'accumulation is disproportionately concentrated in the hands of the best-off groups in the best-off states' (Lerche 2014, 51). As we will see, it is probable that sustained accumulation for large farmers ties up with their abilities to diversify economically. I would add that these tendencies do not, in fact, contradict the notion of a food regime crisis in light of the broader accumulation cycle. Perceiving the crisis as process and relation, it is not to be expected to be anything but uneven. 
Jostein Jakobsen, accepted version, Geoforum

What the Green Revolution did, as is well known, was to put Indian agriculture on a particular path of agro-industrialization. Whereas McMichael tends, as we have seen, to emphasize the 'corporate' influence in restructuring food regimes, Indian agroindustrialization took a decentralized form, driven largely by agrarian capitalists in cohort with the state. As Patel also emphasizes, the early stage of Green Revolution farming was heavily state-reliant, with elaborate systems of protectionist measures established from the late 1960s onwards. These systems, which comprises the country's Public Distribution System, Minimum Support Prices and other forms of subsidies, became in effect the lifeline of agrarian capitalism in India (e.g. Dorin and Landy 2009). Conversely, capitalist farmers, whose political power had grown with commercialization in the late $19^{\text {th }}$ century (Desai 2016), became the lifeline of the developmental state by providing vital political support. The country's bourgeois elites in the Congress Party were, as the political economy of the Indian state teaches us, relatively feeble in their hold over the countryside, necessitating class coalitions with dominant capitalist farmers (Bardhan 1998). The latter comprised not only the richest strata of rural society but also, importantly, the 'bullock capitalists' of 'small to medium-sized self-employed independent agricultural producers' (Rudolph and Rudolph 1987, 50). In Gramscian terms we can perceive this as the integral state at work. As we will see in the next section, it thus follows that the farming blocs of the integral state later came to focus, precisely, on these protectionist measures in mobilizing for their class interests. Unlike Latin-American countries, from which McMichael arguably derives much of his model, the agrarian structure in India is thus not characterized by an opposition between smallholding and massive agribusiness. Agrarian capitalism is, again, decentralized and agribusiness is 'dominated by small-scale, informal firms' (Frödin 2013, 230, see also Harriss-White 2002). International capital knows this. As a US Department of Agriculture report, for example, writes: 'Even though India has one of the world's largest agricultural economies, Indian 
Jostein Jakobsen, accepted version, Geoforum

agribusiness is characterized by a multitude of small-scale, nonintegrated processing and marketing firms that use mostly outdated technology and are uncompetitive in global markets' (Landes 2008, iii).

Richard Walker's notion of 'petrofarming' is highly apt here, pointing to a 'production regime' (Walker 2004, 139) centered on circuits of agro-chemicals. 'The (il)logical end of petrofarming is to eliminate the land as the basis of production' (Walker 2004, 191) by seeking to replace soil nutrients with fertilizers, replace microorganisms with pesticides. Nature appears, in this production regime, so Cheap that it can be totally dispensed with. This is, of course, an illusion. As Tony Weis puts it, we are dealing here with a variety of an industrialized agricultural model based on progressive 'overrides' of biophysical contradictions (Weis 2010). Recent research shows that the Indian Green Revolution heartlands, focused on wheat and rice production, started showing levelling and then falling yields in the 1990s and 2000s 'unless additional agro-chemical inputs were applied' indicative of a 'technological treadmill, in which farmers have had to add ever larger quantities of inputs just to maintain production levels' (Pritchard et al. 2014, 56).

After the petrofarming accumulation cycle kicked off in fertile alluvial valleys with irrigation facilities, particularly in Northwest India (Punjab, Haryana, Western Uttar Pradesh), it then spread across large swaths of the country. Petrofarming went from being confined to regions that were water rich to pop up in semi-arid regions in the course of the following decades (Gulati and Kelley 1999). Take the Yellow Revolution. Much less familiar than its Green big brother, the expansion of crops such as soybeans in semi-arid Central India took off from the 1970s. Richa Kumar's ethnographic study of soybean cultivation in Madhya Pradesh shows that expansion 'developed largely as a result of replicating the green revolution package strategy' (Kumar 2016, 154). The result, Kumar argues, is a 'constancy of crisis' for livelihoods and environments where the agricultural model has 'pushed farmers onto a 
Jostein Jakobsen, accepted version, Geoforum

technological treadmill' where farmers 'find themselves in a position where their long-term reproduction - the need to be able to farm in the future - is increasingly under threat' (Kumar 2016, 155). These crop expansions can thus be seen as expanded accumulation by appropriation - incorporating the work/energy of new agricultural regions - resting on tenuous socioecological grounds.

That these expansions have involved the appropriation of frontiers of Cheap Nature as Moore suggests is clear. One word: water. First water-rich regions, later semi-arid parts of the country became enmeshed in petrofarming, leading to severe strain on water resources. Irrigation through boreholes spread, entailing dependency on electricity. Consequently, we find that much agitation among farmers has revolved around the politics of electricity access, leading in some cases (e.g. Andhra Pradesh, Telangana and Punjab) to heavy subsidization by state governments. The predictable result has been rapid exhaustion of groundwater reserves: 'Between 1980 and 1998 [...] almost 30 percent of Indian districts saw the level of their groundwater reserves drop by at least 4 m' (Dorin and Landy 2009, 177). Coupled with the effects of climate change, agrarian India faces a lethal cocktail - reports of desertification abound, one recent report holding that 'nearly 30 percent of India is degraded or facing desertification' (Staff 2017). This next, and hitherto last, stage of the accumulation cycle thus shows clear signs of rising capitalization in the face of accelerating biophysical contradictions such as, inter alia, soil erosion, toxification of waters, groundwater depletion, weed invasions.

It is in this context that we should view the neoliberalisation of India's agro-food system, which started in the late 1980s, then undergoing an uneven, incomplete and rather cautious process of opening to private capital, breaking down of barriers to accumulation and dismantling of state protectionism. The impact of neoliberal restructuring on India's agrofood system has been subject of much recent scholarship. Prabhat Patnaik provides a useful concise summary: 
Jostein Jakobsen, accepted version, Geoforum

a reduction of input subsidies; a gradual winding down of institutional credit to agriculture, forcing the peasantry to turn to private moneylenders as in colonial times; a dismantling of the insulation between world market and domestic agricultural prices; a whittling down of publicly funded research for improving agricultural practices; a decimation of the public extension network that had been set up earlier; and a retreat from the commitment to a universal public distribution system [...] This withdrawal of support by the state makes agriculture an economically unviable occupation for large segments of the peasantry, much larger than ever before in the post-colonial period (Patnaik 2014, 11)

The claim regarding the economic unviability of agriculture for larger sections of the rural population is borne out in numerous recent statistics, showing the decline of agriculture's share of GNP to a present point of $17.5 \%$ according to official numbers $;{ }^{5}$ low economic growth in agriculture; declining welfare indicators for agriculturalists; and, most spectacularly, rising suicide rates in many agricultural regions (e.g. Vakulabharanam and Motiram 2011). These negative indicators converge with a process of miniaturization of landholdings in the context of an expanding rural workforce (Dorin 2017, 11). Landholdings classified in censuses as 'marginal' (less than one hectare) are now strikingly predominant across the Indian countryside: more than $70 \%$ of landholdings are marginal (see Figure 1).

\section{[FIGURE 1]}

Now, the organizational structures underpinning the petrofarming cycle of accumulation were, as we have seen, based on forms of state interventionism favoring dominant groups in the integral state that gradually disappeared. As several scholars have noted, the neoliberal period in India saw the formerly dominant class coalitions change as the Indian state became increasingly dominated by corporate capital (Gupta and Sivaramakrishnan 2011, Kohli 2012). With the opening up of the economy came increasing exposure to international markets for

\footnotetext{
${ }^{5}$ According to Dorin and Aubron (2016), the share is in reality closer to $14 \%$.
} 
Jostein Jakobsen, accepted version, Geoforum

agricultural commodities with their boom-and-bust fluctuations. ${ }^{6}$ Moreover, with the commodification through petrofarming came also skyrocketing reliance on credit - and thus skyrocketing loan rates - in order to maintain input expenditure as well as wage labor (Suri 2006, Narasimha Reddy and Mishra 2009b). Increased exposure to international market prices entailed that farmers often turned to excessive loans - often from private moneylenders, as public banks drastically reduced their rural presence in the neoliberal period. All of the above make for challenging conditions for smallholder capitalist agriculture. Enter suicides (Kennedy and King 2014, Vasavi 2012).

It appears that the neoliberal state's ongoing attempted 'exit' from its long-held involvement in the Green Revolution model involves, also, attempted socioecological fixes in the context of underproduction of Cheap Nature. Similarly to how Moore argues that neoliberal capitalism lacks ability to bring about new productivity increases in agriculture, the Indian experience of neoliberalism has not managed to fix the crisis tendencies carried over from the second food regime. Among attempted socioecological fixes we find the Indian state's push towards a so-called 'Second Green Revolution'. The phrase first appeared in the 1980s, when it was used simply to denote arguments, not only among policy makers but also in farmer agitations, for extending the petrofarming model to new areas of India, ostensibly to raise productivity (e.g. Sharma 1988). In the 2000s, the idea has become more widespread in policy making discourse, now denoting an explicitly agribusiness-led model where state involvement is sought reduced, public-private partnerships increased in order to 'bring the food markets in India in a tighter embrace with the international food economy' (Bajpai 2015, 291). Whether socioecological fixes of this kind will manage to put neoliberal

\footnotetext{
${ }^{6}$ As John Harriss' $(1982,110)$ classic study from Tamil Nadu shows, Green Revolution technologies were, from the start, designed such that local economies became dependent on external resources - seeds, fertilisers, electricity, etc. - but these dependencies only heightened with the removal, from liberalisation onwards, of barriers to international price fluctuations.
} 
Jostein Jakobsen, accepted version, Geoforum

accumulation on a new track - or even initiate a new cycle of accumulation - remains to be seen.

\subsection{Farmers' movements and the provincial propertied classes}

As I am writing this, the plight of India's farmers makes daily headlines in national newspapers - and even beyond. During the spring months of 2017, India witnessed a series of protests spearheaded by farmers, where issues related to agrarian crisis were emphasized: debt traps, drought, suicides, degraded livelihoods and environments. Agitations across several states saw farmers demanding loan waivers and higher minimum support prices from the government. Some protests turned violent, resulting in police forces killing several farmers in Maharashtra. Moreover, dramatic increase in 'agrarian riots' have been reported in the last couple of years. In short, India's agrarian crisis flies in your face. While some scholars quickly termed the ongoing protests 'the return of kisan [farmer] politics' (Jaffrelot 2017), it is rather the case that the protests were only at best partially organized mobilizations - more usefully seen as ad hoc initiatives. As I will return to shortly, other recent protests have been spearheaded by dominant farmers such as the Jats in Haryana and the Patels in Gujarat. Yet, despite the energy of these recent agitations, they pale in comparison to earlier farmer mobilizations. Take for example the rally that New Delhi witnessed in late 1978, when somewhere around half a million farmers mobilized to 'ventilate their grievances', as their leader Charan Singh expressed it (Chawla 1979). Nevertheless, the recurrent appearance of agrarian crisis as a problematic in the Indian public sphere appears to prove that the crisis has indeed been 'named' in Friedmann's sense. The media, farmers, rights activists as well as the government in numerous recent reports concur that something is rotten in the state of agriculture. As Lerche puts it in a review of agrarian crisis literature: 'The Indian government, academics and farmers all agree: Indian agriculture is in crisis' (Lerche 2011, 104). 
Jostein Jakobsen, accepted version, Geoforum

Yet smallholder oriented counter-movements are strikingly absent. How do we then understand such absence despite the real presence of both accumulation crisis and legitimation crisis?

Times have certainly changed since Charan Singh mobilized farmers in great numbers. This was the period, in the 1970s and 1980s, when India witnessed the flourishing of what came to be known as the 'new' farmers' movements in several parts of the country (Brass 1995b). Among the most important of these were, inter alia, the Shetkari Sanghatana based in Maharashtra, the Bharatiya Kisan Union in various parts of North India, the Bharatiya Kisan Sangh in Gujarat and the Karnataka Rajya Ryota Sangha in Karnataka (Brass 1995a, 3). Some of these still exist, although now in reduced strength. How 'new' they were has been strongly contested: they relied largely on long-held patterns of power in agrarian social structures. At the very least, their newness consisted in their ability to bring farmers' interests to national attention. What did such 'interests' consist of? These movements were often of a distinct class character, in stark contradiction to their often professed ideologies of 'an undifferentiated rural universe' (Byres 1995, 2). Class interests revolved around that of farmers who had become integrated in capitalist markets with the Green Revolution, where the search for more, better and cheaper inputs and support from the state proved to be a main axis of contestation (Brass 1995a). It can be useful for our purposes to follow K. Balagopal in speaking of the 'provincial propertied classes' (PPCs) as the main class force behind these farmers' movements. Writing in 1987 - in other words, in the midst of the surge of these movements - Balagopal described the PPCs as follows:

A typical family of this provincial propertied class has a landholding in its native village, cultivated by hired labour, bataidars, tenants or farm-servants and supervised by the father or one son; business of various descriptions in towns-trade, finance, hotels, cinemas and contracts - managed by other sons; and perhaps a young and 
Jostein Jakobsen, accepted version, Geoforum

bright child who is a doctor or engineer or maybe even a professor at one of the small town universities that have sprouted all over the country during the last two decades (Balagopal 1987, 1545).

The PPCs are not exclusively 'farmers', then (cf. Upadhya 1988). As a recent overview of the agrarian crisis shows, these classes 'used their prosperity to straddle both the rural and urban sectors and have diversified their sources of income (e.g. real estate, trading, etc.). Despite the reduced profitability in agriculture, they have managed to protect themselves' (Vakulabharanam and Motiram 2011, 118-119). The less prosperous lower-middle sections of farmers experienced neoliberal farm in the agro-food system more threatening. But aspirations for middle class lifestyles had, by the 1990s, become the new norm in rural areas; smallholding agriculture was increasingly seen not as the future but as the past (Jeffrey 2010). The least resourceful petrofarmers that are presently suffering from neoliberal restructuring at the height of accumulation crisis appear, in such a perspective, as the sections that have not been able to diversify out of agriculture and are now left in a 'shadow space' where widespread disenchantment with agriculture combines with a neoliberal 'political economy of uncaring' (Vasavi 2012). Consequently the reserve army of labor in India is expanding rapidly. Among the laboring classes in the Indian countryside, moreover, the last couple of decades has seen the expansion of employment outside of agriculture with widespread labor migration - counting at least 50 million people, according to Jan Breman $(2010,7)$. This means that 'agriculture is no longer the primary basis of material reproduction of rural-based labouring class households' (Pattenden 2016, 216). In this scenario, labor is undergoing marked fragmentation and the emergence of counter-movements of and for smallholding farming among these sections of the rural population appears unlikely.

Radhika Desai argues compellingly that India's turn to neoliberalism should be seen, not as a state-initiated venture from the late $1980 \mathrm{~s}$, but rather as a 'slow-motion counterrevolution' 
Jostein Jakobsen, accepted version, Geoforum

where landed agrarian elites and dominant middle-caste farmers worked against the developmental state's attempts at progressive reform in agriculture after Independence.

Breaking apart state planned land reform, these dominant farmers 'organized an agrarian transition of their own devising, on their own terms' (Desai 2016, 28), whereby Indian neoliberalism was shaped to their interests - rather than to large corporate capital, as in the West. This involved a turn to capitalist agriculture with the Green Revolution that was shaped to these farmers' interests and that, consequently, made them into 'agricultural bourgeoisies'(Desai 2016, 38). As the initial accumulation phase plateaued and even decelerated within the next decade, the agricultural bourgeoisies diversified out of farming and 'turned to industrial and agricultural investments' (Desai 2016, 39, Bardhan 1998, 64). While these dominant farmers used farmers' movements in the 1970s in order to push their demands from the state, diversification led this to change and 'by the $1980 \mathrm{~s}$, farmers' movements proved too narrow as platforms for the widening interests of the dominant castes' (Desai 2016, 42). In sum, this often ignored trajectory of dominant class interests in rural India enables us to see, in part, why farmers' movements eventually lost much of their momentum. To the extent that dominant farmers are mobilizing as blocs - such as we have seen recently in protests among Jats in Haryana and Patels in Gujarat - this is not for the cause of smallholding farming but rather for reservation quotas in order to gain access to education and government posts. ${ }^{7}$ This shows that the provincial propertied classes are not uniformly successful in their diversification strategies. Groups that fall behind - also facing poverty - do not, however, see small-scale agriculture as the favored way out.

One of the most prominent new farmers' movements is the KRRS, still active in parts of Karnataka. KRRS gained particular fame internationally in the early 1990s for its aggressive

\footnotetext{
${ }^{7}$ Both Jats and Patels - being dominant castes in their respective regions - have been agitating for classification as 'Other Backward Classes' and the quota rights this classification brings (see e.g. Hindu 2016, Iyengar 2015). 
Jostein Jakobsen, accepted version, Geoforum

stand and direct action strategies against multi-national companies as well as its membership in Via Campesina. The fame led Raj Patel (2012), in his activist writings, to perceive KRRS as at the forefront of promising struggles for farmers' dignity. Yet KRRS was in many ways not a progressive organization - except in its rhetoric. Jonathan Pattenden (2005) shows, through ethnographic research among KRRS activists and in villages where KRRS enjoys support, a stark contrast between rhetorical emphasis on anti-capitalist mobilization and lived experience of domination. He finds that in practice, KRRS supporters are primarily upper caste/class farmers - village elites - engaged in capitalist agriculture, while relying on exploitative labor relations and patriarchal as well as casteist power structures. Pattenden (2016, 224-226) argues that, since the mid-1990s, rising diversification in the economic bases of capitalist farmers as well as the incorporation of these farmers in the local state played an important role in the decline of the KRRS over time. Recently, prominent scholars of Via Campesina have taken heed of the less than progressive stand and upper class nature of the KRRS (Edelman and Borras Jr 2016, 46-47).

An apparent challenge to my argument is found in Daniel Münster's (2016) recent ethnographic research in Kerala. Here, Münster argues that a smallholder oriented agroecological movement known as Zero Budget Natural Farming (ZBNF) constitutes precisely a Polanyian double movement to socioecological crisis. Responding to the agrarian crisis, ZBNF seeks, in Münster's view, no less than repairing the metabolic rift of capitalist agriculture. Centered on charismatic leader Subhash Palekar, ZBNF promotes an alternative agronomy where the minimizing of market and capital dependency is central. ZBNF has spread in South India in the last decade or so, presently constituting what Khadse et al. (2017, 3) characterize as a 'massive grassroots social movement'. Numbers are however hard to ascertain. Münster rather uncritically quotes Palekar in holding - wholly unbelievably - that there are '30 million practitioners in South India', while in the same instance saying that there 
Jostein Jakobsen, accepted version, Geoforum

are 80-100 organized in his own field site in Kerala (Münster 2016, 234). Khadse et al. hold that 'a rough estimation for just Karnataka puts the figure there at around 100,000' (Khadse et al. 2017, 3). All of these estimates are seemingly based on self-presentation by ZBNF leaders and cannot be taken at face value.

While Münster clearly presents us with an interesting phenomenon in the form of ZBNF, I find that his analysis also presents us with an instructive example of the pitfalls of Polanyian readings. Restricting myself to Münster's work, the following critical remarks are not meant to be generalizing about the potential of agroecological alternatives in India. ${ }^{8}$ I want to highlight three - in a Gramscian perspective problematic - issues. Münster acknowledges that ZBNF consists of 'former' capitalist farmers turned down by the agrarian crisis of spiraling debt and labor costs in particular. These farmers profess beliefs in the sanctity of the Indian cow that puts them into 'ideological proximity' to Hindu nationalist chauvinism, with its clear upper caste bias (Münster 2016, 235). As these points entail that ZBNF 'is not an easy partner for transformative politics in India' (Münster 2016, 239), Münster therefore seems willing to define, as Polanyi himself, counter-movements regardless of political ideologies. A Gramscian take would object strongly to such a wide net, unable as it is to differentiate the politically progressive from the reactionary. A more rigorous class analysis would, moreover, probably have helped Münster spell out the agrarian elite position of the ZBNF practitioners. Here, Khadse et al. are more helpful in pointing out that in Karnataka, ZBNF has evolved in close connection to the KRRS. Consequently, ZBNF practitioners are primarily from KRRS support groups, namely propertied and upper/middle castes (Khadse et al. 2017, 7-8). ZBNF has therefore only to a very limited extent taken hold among lower class

\footnotetext{
${ }^{8}$ Notice can be made that there are initiatives such as the Kisan Swaraj (http://www.kisanswaraj.in), which may look like counter-movements, purporting to organize farmers along agroecological lines. However, apart from websites and rare press statements, it is hard to find evidence that these initiatives really engage in much actual mobilization.
} 
Jostein Jakobsen, accepted version, Geoforum

groups and should be seen, rather than an allegedly Polanyian double movement, as the working of distressed PPCs who find debt traps and labor costs unmanageable in the context of an exhausted cycle of accumulation. ${ }^{9}$

There are also other signs, except exhaustion, that the long green revolution cycle of accumulation is reaching its end. As farmers have diversified out of agriculture, we find that agricultural land, not coincidentally, increasingly finds new usages and value through financialization. As Nikita Sud shows, 'since 1990-1991, over 5 million hectares have been transferred to non-agricultural uses such as industry and infrastructure' (Sud 2017, 80). This fits into the neoliberal pattern of redistributing assets to the upper classes by 'transferring landed wealth and resources upwards' (Oskarsson and Nielsen 2017, 8, cf. Harvey 2005). While it is still perhaps too early to tell how the agrarian crisis as a food regime crisis will give birth to new cycles of accumulation, these are clues to emerging patterns.

\section{CONCLUSION}

This article aimed at contributing to theorizing crisis and counter-movements in food regime analysis in a Gramscian political ecological framework. In doing, so it took India's ongoing actually existing agrarian crisis as its case of focus, aiming for an incipient understanding of why smallholder counter-movements are strikingly absent in India. Despite the co-presence of socioecological accumulation crisis and legitimation crisis, the case of India does not evince sustained mobilization among smallholders, thus constituting an analytical problem for food regime analysis. I have argued for a Gramscian perspective that problematizes the Polanyian framework - foundational to much food regime research - where 'society' is seen

\footnotetext{
${ }^{9}$ Research from another 'natural farming' initiative in Haryana similarly shows that distressed PPCs are the main elements involved apart from middle-class activists - all in all restricted to a 'niche position' (Brown 2013, 242). Apart from distress, health concerns also matter. It is interesting to note that there is a tendency for farmers to convert only parts of their land for agroecological methods for own consumption, while keeping remaining land under agrochemicals for sale (Brown 2013, 238-239). Based on fieldwork in Kerala in 2015, I have indications that similar dynamics are found among ZBNF practitioners in Kerala.
} 
Jostein Jakobsen, accepted version, Geoforum

as separate from the 'state' and the 'market'. Instead, a Gramscian food regime analysis would start by looking at state-society relations as key to understanding the making of capitalist hegemony in particular historical-geographical contexts - including, that is, particular class constellations.

In terms of rethinking the theory of resistance embedded in food regime analysis, it thus appears doubtful that a smallholder farming counter-movement is what we should rest our expectations on in the case of India's actually existing agrarian crisis. The prospect of forms of resistance to agrarian crisis that addresses the class forces that rule the countryside through the integral state - subordinating and exploiting subaltern groups - should be located, theoretically speaking, elsewhere. We have seen that the 'victims' of the agrarian crisis are largely also its 'perpetrators': agrarian capitalists, not the least smallholder varieties thereof. Large sections of Indian farmers have vigorously been pursuing petrofarming through the dialectics of appropriation and capitalization of Cheap Nature in a cycle of accumulation that now appears close to exhausted.

Moreover, petrofarming has been based on the appropriation and exploitation of 'Cheap Labor' (Moore 2015). This relates to the ways by which ongoing 'accumulation by dispossession' (Harvey 2003) across India has brought vast amounts of poor rural groups into an ever-expanding reserve army of labor. An interesting line of argument would involve looking into how capitalist agriculture is, to a large extent, upheld through crisis by reliance on migrant labor-power. Refocusing the capital-labor relation as a central axis for food regime resistance would enable theories of mobilization that takes heed of existing class forces, avoiding the limitations found in McMichael's readings of Polanyi of seeing undifferentiated 'society' as catalyst of counter-hegemony. Such refocusing could help us work towards the goal stipulated in the introduction, namely a food regime analysis with 'political sensitivity toward the subordinate classes as a whole, not merely the peasantry' 
Jostein Jakobsen, accepted version, Geoforum

(Otero 2016, 303). Counter-hegemonic mobilization is, as Gramsci famously wrote, constructed out of existing conditions in order for 'the present be welded to the future' (Gramsci 2000, 79). The prospects do not seem bright. Yet thinking beyond smallholders could help pave the way for a Gramscian theory of progressive resistance to the contemporary food regime. 
Jostein Jakobsen, accepted version, Geoforum

\section{REFERENCES}

Araghi, Farshad. 2009. "Accumulation by Displacement: Global Enclosures, Food Crisis, and the Ecological Contradictions of Capitalism." Review (Fernand Braudel Center) 32 (1):113-146.

Arrighi, Giovanni. 2010. The Long Twentieth Century: Money, Power and the Origins of Our Times. Second ed. London \& New York: Verso.

Bajpai, Vikas. 2015. "India's Second Green Revolution: Portends for Future and Possible Alternatives." Agrarian South: Journal of Political Economy 4 (3):289-326. doi: doi:10.1177/2277976016633343.

Balagopal, K. 1987. "An Ideology for the Provincial Propertied Class." Economic and Political Weekly:1544-1546.

Bardhan, Pranab. 1998. The Political Economy of Development in India. Second ed. Delhi: Oxford University Press.

Bernstein, Henry. 2014. "Food sovereignty via the "peasant way': a sceptical view." The Journal of Peasant Studies 41 (6):1031-1063. doi: 10.1080/03066150.2013.852082.

Bernstein, Henry. 2016. "Agrarian political economy and modern world capitalism: the contributions of food regime analysis." The Journal of Peasant Studies 43 (3):611647. doi: 10.1080/03066150.2015.1101456.

Block, Fred. 2008. "Polanyi's double movement and the reconstruction of critical theory." Revue Interventions économiques. Papers in Political Economy (38).

Brass, Tom. 1995a. "Introduction: The New Farmers' Movements in India." In New Farmers' Movements in India, edited by Tom Brass, 3-27. London: Frank Cass.

Brass, Tom, ed. 1995b. New Farmers' Movements in India. London: Frank Cass.

Brass, Tom. 2015. "Peasants, academics, populists: Forward to the past?" Critique of Anthropology 35 (2):187-204. doi: doi:10.1177/0308275X15569853.

Breman, Jan. 2010. Outcast Labour in Asia: Circulation and Informalization of the Workforce at the Bottom of the Economy. New Delhi: Oxford University Press.

Brown, Trent. 2013. "Agrarian Crisis in Punjab and 'Natural Farming' as a Response." South Asia: Journal of South Asian Studies 36 (2):229-242. doi: 10.1080/00856401.2013.776002.

Burawoy, Michael. 2003. "For a Sociological Marxism: The Complementary Convergence of Antonio Gramsci and Karl Polanyi." Politics \& Society 31 (2):193-261. doi: doi:10.1177/0032329203252270.

Byres, Terence J. 1995. "Preface." In New Farmers' Movements in India, edited by Tom Brass, 1-2.

Carroll, William K. 2010. "Crisis, movements, counter-hegemony: in search of the new." Interface: a journal for and about social movements 2 (2):168-198.

Castellanos-Navarrete, Antonio, and Kees Jansen. 2017. "Why do smallholders plant biofuel crops? The 'politics of consent' in Mexico." Geoforum 87 (Supplement C):15-27. doi: https://doi.org/10.1016/j.geoforum.2017.09.019.

Chatterjee, Partha. 2004. The Politics of the Governed: Reflections on Popular Politics in Most of the World. New York: Columbia University Press.

Chawla, Prabhu. 1979. "Numbers' game." India Today, January 15. http://indiatoday.intoday.in/story/kisan-rally-fifty-lakh-farmers-participate-in-charansinghs-political-circus/1/427069.html.

Dale, Gareth. 2012. "Double movements and pendular forces: Polanyian perspectives on the neoliberal age." Current Sociology 60 (1):3-27. doi: 10.1177/0011392111426645. 
Das, Raju J. . 2017. "Social Movements and State Repression in India." Journal of Asian and African Studies 52 (8):1080-1102. doi: 10.1177/0021909616653258.

Davis, Mike. 2006. Planet of Slums. London: Verso.

Desai, Radhika. 2016. "The Slow-Motion Counterrevolution: Developmental Contradictions and the Emergence of Neoliberalism." In Social Movements and the State in India: Deepening Democracy?, edited by Kenneth Bo Nielsen and Alf Gunvald Nilsen, 2551. London: Palgrave Macmillan UK.

Dorin, Bruno. 2017. "India and Africa in the Global Agricultural System (1961-2050): Towards a New Sociotechnical Regime?" Economic and Political Weekly LII (25 \& 26):5-13.

Dorin, Bruno, and Claire Aubron. 2016. "Croissance et revenu du travail agricole en Inde. Une économie politique de la divergence (1950-2014)." Économie rurale 352 (2):4165.

Dorin, Bruno, and Frédéric Landy. 2009. Agriculture and Food in India: A Half-century Review from Independence to Globalization. New Delhi: Manohar.

Edelman, Marc, and Saturnino M. Borras Jr. 2016. Political Dynamics of Transnational Agrarian Movements. Rugby: Fernwood Publishing \& Practical Action Publishing.

Ekers, Michael, and Scott Prudham. 2015. "Towards the socio-ecological fix." Environment and Planning A 47 (12):2438-2445. doi: doi:10.1177/0308518X15617573.

Ekers, Michael, and Scott Prudham. 2017a. "The Metabolism of Socioecological Fixes: Capital Switching, Spatial Fixes, and the Production of Nature." Annals of the American Association of Geographers:1-19. doi: 10.1080/24694452.2017.1309962.

Ekers, Michael, and Scott Prudham. 2017b. "The Socioecological Fix: Fixed Capital, Metabolism, and Hegemony." Annals of the American Association of Geographers:118. doi: 10.1080/24694452.2017.1309963.

Friedmann, Harriet. 1993. "The Political Economy of Food: A Global Crisis." New Left Review 197 (1):29-57.

Friedmann, Harriet. 2005. "From Colonialism to Green Capitalism: Social Movements and Emergence of Food Regimes." In New Directions in the Sociology of Global Development, edited by Frederick H. Buttel and Philip McMichael, 227-264. Oxford: Elsevier.

Friedmann, Harriet, and Philip McMichael. 1989. "Agriculture and the state system: The rise and decline of national agricultures, 1870 to the present." Sociologia Ruralis 29 (2):93-117. doi: 10.1111/j.1467-9523.1989.tb00360.x.

Frödin, Olle. 2013. "Modernization, neo-liberal globalization, or variegated development: the Indian food system transformation in comparative perspective." International Review of Sociology 23 (1):221-242. doi: 10.1080/03906701.2013.771047.

Gramsci, Antonio. 1971. Selections from the Prison Notebooks. New York: International Publishers.

Gramsci, Antonio. 2000. "Workers' Democracy." In The Gramsci Reader: Selected Writings 1916-1935, edited by David Forgacs, 79-82. New York: New York University Press.

Gulati, Ashok, and Tim Kelley. 1999. Trade Liberalization and Indian Agriculture: Cropping Patten Changes and Efficiency Gains in Semi-Arid Tropics. New Delhi: Oxford University Press.

Gupta, Akhil. 1998. Postcolonial Developments: Agriculture in the Making of Modern India. Durham, NC: Duke University Press Books.

Gupta, Akhil, and K. Sivaramakrishnan. 2011. "Introduction: The state in India after liberalization." In The State in India after Liberalization: Interdisciplinary Perspectvies, edited by Akhil Gupta and K. Sivaramakrishnan, 1-27. Oxford and New York: Routledge. 
Harriss-White, Barbara. 2002. India Working: Essays on Society and Economy. Cambridge ; New York: Cambridge University Press.

Harriss, John. 1982. Capitalism and Peasant Farming: Agrarian Structure and Ideology in Northern Tamil Nadu. Bombay: Oxford University Press.

Harriss, John. 2011. "How Far Have India's Economic Reforms Been Guided by Compassion and Justice? Social Policy in the Neoliberal Era." In Understanding India's New Political Economy: A Great Transformation?, edited by Sanjay Ruparelia, Sanjay Reddy, John Harriss and Stuart Corbridge, 127-140. London: Routledge.

Harvey, David. 2001. "Globalization and the spatial fix." Geographische revue 2 (3):23-31.

Harvey, David. 2003. The New Imperialism. New York: Oxford University Press.

Harvey, David. 2005. A Brief History of Neoliberalism. Oxford: Oxford University Press.

Hindu, The. 2016. "Jat quota protests: What is it all about?" The Hindu, February 20. http://www.thehindu.com/specials/jat-quota-protests-what-is-it-allabout/article14091994.ece1.

Holt Giménez, Eric, and Annie Shattuck. 2011. "Food crises, food regimes and food movements: rumblings of reform or tides of transformation?" The Journal of Peasant Studies 38 (1):109-144. doi: 10.1080/03066150.2010.538578.

Iyengar , Rishi 2015. "Riots Break Out in India Over a Dominant Caste's Attempt to Gain 'Backward' Status." Time, August 26. http://time.com/4011001/hardik-patel-protestarrest-gujarat-obcl.

Jaffrelot, Christophe. 2017. "The return of kisan politics." The Indian Express, June 24. http://indianexpress.com/article/opinion/columns/the-return-of-kisan-politics4719127/.

Jansen, Kees. 2015. "The debate on food sovereignty theory: agrarian capitalism, dispossession and agroecology." The Journal of Peasant Studies 42 (1):213-232. doi: 10.1080/03066150.2014.945166.

Jeffrey, Craig. 2010. Timepass: Youth, Class, and the Politics of Waiting. Stanford, California: Stanford University Press.

Kennedy, Jonathan, and Lawrence King. 2014. "The political economy of farmers' suicides in India: indebted cash-crop farmers with marginal landholdings explain state-level variation in suicide rates." Globalization and Health 10:16. doi: 10.1186/1744-860310-16.

Khadse, Ashlesha, Peter Michael Rosset, Helda Morales, and Bruce G. Ferguson. 2017. "Taking agroecology to scale: the Zero Budget Natural Farming peasant movement in Karnataka, India." The Journal of Peasant Studies:1-28. doi: 10.1080/03066150.2016.1276450.

Kohli, Atul. 2012. Poverty Amid Plenty in the New India. Cambridge ; New York: Cambridge University Press.

Kumar, Richa. 2016. Rethinking Revolutions: Soyabean, Choupals, and the Changing Countryside in Central India. New Delhi: Oxford University Press.

Landes, Maurice. 2008. The Environment for Agricultural and Agribusiness Investment in India. edited by Economic Research Service: United States Department of Agriculture.

Lerche, Jens. 2011. "Agrarian Crisis and Agrarian Questions in India." Journal of Agrarian Change 11:104-118. doi: 10.1111/j.1471-0366.2010.00295.x.

Lerche, Jens. 2013. "The Agrarian Question in Neoliberal India: Agrarian Transition Bypassed?" Journal of Agrarian Change 13 (3):382-404. doi: 10.1111/joac.12026.

Lerche, Jens. 2014. "Regional patterns of agrarian accumulation in India." In Indian Capitalism in Development, edited by Judith Heyer and Barbara Harriss-White, 4665 . London \& New York: Routledge. 
Loftus, Alex. 2013. "Gramsci, Nature and the Philosophy of Praxis." In Gramsci: Space, Nature, Politics, edited by Michael Ekers, Gillian Hart, Stefan Kipfer and Alex Loftus, 178-197. Oxford: Wiley-Blackwell.

Magnan, André. 2012. "Food regimes." In The Oxford Handbook of Food History, edited by J. M. Pilcher, 370-388. Oxford: Oxford University Press.

Mann, Geoff. 2009. "Should political ecology be Marxist? A case for Gramsci's historical materialism." Geoforum 40 (3):335-344.

Marx, Karl. 1973. Grundrisse: Foundations of the Critique of Political Economy: Penguin.

Marx, Karl. 1976. Capital: Volume 1. London: Penguin.

McMichael, Philip. 2005. "Global Development and the Corporate Food Regime." In New Directions in the Sociology of Global Development, edited by Frederick H. Buttel and Philip McMichael, 269-303. Oxford: Elsevier Press.

McMichael, Philip. 2006. "Peasant prospects in the neoliberal age." New Political Economy 11 (3):407-418. doi: 10.1080/13563460600841041.

McMichael, Philip. 2009a. "A food regime analysis of the "world food crisis'." Agriculture and Human Values 26:281-295. doi: 10.1007/s10460-009-9218-5.

McMichael, Philip. 2009b. "A food regime genealogy." The Journal of Peasant Studies 36 (1):139-169. doi: 10.1080/03066150902820354.

McMichael, Philip. 2009c. "Interpreting the World Food Crisis of 2007-08." Review (Fernand Braudel Center) 32 (1):1-8.

McMichael, Philip. 2013. Food Regimes and Agrarian Questions. Rugby: Fernwood Publishing and Practical Action Publishing.

McMichael, Philip. 2016. "Commentary: Food regime for thought." The Journal of Peasant Studies 43 (3):648-670. doi: 10.1080/03066150.2016.1143816.

Moore, Jason W. 2011. "Transcending the metabolic rift: a theory of crises in the capitalist world-ecology." The Journal of Peasant Studies 38 (1):1-46. doi: $10.1080 / 03066150.2010 .538579$.

Moore, Jason W. 2015. Capitalism in the Web of Life: Ecology and the Accumulation of Capital. London and New York: Verso.

Moore, Jason W. 2016. "The Rise of Cheap Nature." In Anthropocene or Capitalocene? Nature, History, and the Crisis of Capitalism, edited by Jason W. Moore, 78-116. Oakland, CA: PM Press.

Moore, Jason W. 2017. "The Capitalocene Part II: accumulation by appropriation and the centrality of unpaid work/energy." The Journal of Peasant Studies:1-43. doi: 10.1080/03066150.2016.1272587.

Münster, Daniel. 2015. "“Ginger is a gamble”: Crop booms, rural uncertainty, and the neoliberalization of agriculture in South India." Focaal: Journal of Global and Historical Anthropology 2015 (71):100-113. doi: 10.3167/fcl.2015.710109.

Münster, Daniel. 2016. "Agro-ecological double movements? Zero Budget Natural Farming and alternative agricultures after the neoliberal crisis in Kerala." In Critical Perspectives on Agrarian Transition: India in the global debate, edited by B. B. Mohanty, 222-245. London and New York: Routledge.

Narasimha Reddy, D., and Srijit Mishra, eds. 2009a. Agrarian Crisis in India. New Delhi ; New York: Oxford University Press.

Narasimha Reddy, D., and Srijit Mishra. 2009b. "Agriculture in the Reforms Regime." In Agrarian Crisis in India, edited by D. Narasimha Reddy and Srijit Mishra, 3-44. New Delhi Oxford University Press.

Nielsen, Kenneth Bo, and Alf Gunvald Nilsen. 2015. "Law Struggles and Hegemonic Processes in Neoliberal India: Gramscian Reflections on Land Acquisition Legislation." Globalizations 12 (2):203-216. doi: 10.1080/14747731.2014.937084. 
Nilsen, Alf Gunvald. 2009. "The authors and the actors of their own drama': Towards a Marxist theory of social movements." Capital \& Class 33 (3):109-139. doi: doi:10.1177/03098168090330030501.

O'Connor, James. 1998. Natural Causes: Essays in Ecological Marxism. New York: Guilford Press.

Oskarsson, Patrik, and Kenneth Bo Nielsen. 2017. "Industrialising rural India." In Industrialising Rural India: Land, policy and resistance, edited by Kenneth Bo Nielsen and Patrik Oskarsson, 3-19. London \& New York: Routledge.

Otero, Gerardo. 2012. "The neoliberal food regime in Latin America: state, agribusiness transnational corporations and biotechnology." Canadian Journal of Development Studies / Revue canadienne d'études du développement 33 (3):282-294. doi: 10.1080/02255189.2012.711747.

Otero, Gerardo. 2016. "Review of Philip McMichael's Food Regimes and Agrarian Questions." Journal of World-Systems Research 22 (1):7. doi: 10.5195/jwsr.2016.651.

Otero, Gerardo, Gabriela Pechlaner, and Efe Can Gürcan. 2013. "The Political Economy of "Food Security" and Trade: Uneven and Combined Dependency." Rural Sociology 78 (3):263-289. doi: 10.1111/ruso.12011.

Patel, Raj. 2012. Stuffed and Starved: From Farm to Fork: The Hidden Battle for the World Food System. Second ed. London: Portobello Books.

Patel, Raj. 2013. "The Long Green Revolution." The Journal of Peasant Studies 40 (1):1-63. doi: 10.1080/03066150.2012.719224.

Patnaik, Prabhat. 2014. "Imperialism and the Agrarian Question." Agrarian South: Journal of Political Economy 3 (1):1-15. doi: doi:10.1177/2277976014530229.

Pattenden, Jonathan. 2005. "Horizontality and the Political Economy of Social Movement: The Anti-Capitalist Globalisation Movement, the Karnataka State Farmers Association and Dynamics of Social Transformation in Rural South India." PhD, Department of Development Studies, School of Oriental and African Studies, University of London.

Pattenden, Jonathan. 2016. "Blind Alleys and Red Herrings? Social Movements, the State, Class Alliances and Pro-Labouring Class Strategy." In Social Movements and the State in India: Deepening Democracy?, edited by Kenneth Bo Nielsen and Alf Gunvald Nilsen, 215-239. London: Palgrave Macmillan.

Polanyi, Karl. 2001 [1944]. The Great Tranformation: The Political and Economic Origins of Our Time. Boston: Beacon Press.

Pritchard, Bill. 2009. "The long hangover from the second food regime: a world-historical interpretation of the collapse of the WTO Doha Round." Agriculture and Human Values 26 (4):297. doi: 10.1007/s10460-009-9216-7.

Pritchard, Bill, Jane Dixon, Elizabeth Hull, and Chetan Choithani. 2016. "'Stepping back and moving in': the role of the state in the contemporary food regime." The Journal of Peasant Studies 43 (3):693-710. doi: 10.1080/03066150.2015.1136621.

Pritchard, Bill, Anu Rammohan, Madhushree Sekher, S. Parasumaran, and Chetan Choithani. 2014. Feeding India: Livelihoods, entitlements and capabilities. London and New York: Routledge.

Roitman, Janet. 2014. Anti-Crisis. Durham and London: Duke University Press.

Roseberry, William. 2002. "Understanding Capitalism-Historically, Structurally, Spatially." In Locating Capitalism in Time and Space: Global Restructurings, Politics, and Identity, edited by David Nugent, 61-80. Stanford: Stanford University Press.

Rudolph, Lloyd I., and Susanne Hoeber Rudolph. 1987. In Pursuit of Lakshmi: The Political Economy of the Indian State. Chicago \& London: The University of Chicago Press. 
Sahoo, Sarbeswar. 2017. "Market Liberalism, Marginalised Citizens and Countermovements in India." Asian Studies Review 41 (1):1-19. doi: 10.1080/10357823.2016.1263887.

Sharma, K. K. 1988. "Survey of India (10): Wanted, a new green revolution - Agriculture / Farmers have been protesting over the lack of a fair deal." Financial Times, December 20.

Sinha, Subir. 2017. "'Histories of Power', the 'Universalization of Capital', and India's Modi Moment: Between and Beyond Marxism and Postcolonial Theory." Critical Sociology 43 (4-5):529-544. doi: 10.1177/0896920516641732.

Staff, DTE. 2017. "Desertification has increased in 90 per cent of states in India " Down to Earth, June 07.

Sud, Nikita. 2017. "State, scale and networks in the liberalisation of India's land." Environment and Planning C: Government and Policy 35 (1):76-93. doi: $10.1177 / 0263774 X 16655801$

Sundar, Nandini. 2011. "The rule of law and the rule of property: Law-struggles and the neoliberal state in India." In The State in India after Liberalization: Interdisciplinary Perspectives, edited by Akhil Gupta and K. Sivaramakrishnan, 175-193. London: Routledge.

Sundar, Nandini. 2016. The Burning Forest: India's War in Bastar. New Delhi: Juggernaut.

Suri, K. C. 2006. "Political Economy of Agrarian Distress." Economic and Political Weekly 41 (16):1523-1529.

Upadhya, Carol Boyack. 1988. "The Farmer-Capitalists of Coastal Andhra Pradesh." Economic and Political Weekly 23 (27):1376-1382.

Vakulabharanam, Vamsi, and Sripad Motiram. 2011. "Political economy of agrarian distress in India since the 1990s." In Understanding India's New Political Economy: A Great Transformation?, edited by Sanjay Ruparelia, Sanjay Reddy, John Harriss and Stuart Corbridge, 101-127. London \& New York: Routledge.

Vasavi, A. R. 2012. Shadow Space: Suicides And The Predicament Of Rural India. Gurgaon: Three Essays Collective.

Walker, Richard A. 2004. The Conquest of Bread: 150 Years of Agribusiness in California New York \& London: The New Press.

Weis, Tony. 2010. "The Accelerating Biophysical Contradictions of Industrial Capitalist Agriculture." Journal of Agrarian Change 10 (3):315-341. doi: 10.1111/j.14710366.2010.00273.x.

Whitehead, Judith. 2015. "Au Retour a Gramsci: Reflections on Civil Society, Political Society and the State in South Asia." Journal of Contemporary Asia 45 (4):660-676. doi: 10.1080/00472336.2015.1045725. 